\title{
Study on impact of fiber hybridization in material properties of engineered cementitious composites
}

\author{
Estudo sobre o impacto da hibridização \\ de fibras em propriedades materiais \\ de compósitos cemenciosos \\ engenhados
}

\begin{abstract}
Ammapalyam Ramasamy Krishnaraja ${ }^{1}$, Subbaiyan Anandakumar ${ }^{1}$, Murugesan Jegan ${ }^{1}$, Thottipalayam Sakthivel Mukesh ${ }^{1}$, Krishnamoorthy Sampath Kumar ${ }^{1}$
\end{abstract}

\footnotetext{
${ }^{1}$ Department of Civil Engineering, Kongu Engineering College, Perundurai, Tamilnadu, India. e-mail: krajacivil@gmail.com
}

\begin{abstract}
Engineered Cementitious Composite (ECC) is a type of improved high-performance fiber reinforced cementitious composites with good tensile, compression and flexural behavior. ECC is known for their strainhardening behavior under tension and has been increasingly applied in engineering practice. The process of adding two or more fibers in a mix is known as hybridization. The hybrid composite drives benefits from each of the individual fibers added and exhibits improved ultimate strength and strain capacity compared to the mono-fiber composites. The major applications of ECC are structural reinforcement in the construction and also organic fiber hybridization is valid only for underwater conditions and they will provide additional tests concerning burnability or flammability. This work presents the results obtained from three ECC mixes (PVA, PP, STEEL) and four Hybrid Engineered Cementitious Composites (HECC) with different combinations of volume fraction with PVA, PP, STEEL. The experimental studies have been carried out to investigate the mechanical behaviors of ECC and HECC. The results indicate that this hybridation process has a notable achievement in compressive strength, direct tensile strength and flexural strength.
\end{abstract}

Keywords: Engineered Cementitious Composite, Compressive Strength, Flexural Strength, Direct Tensile Strength, Composites with Organic Burnable Materials

\begin{abstract}
ABSTRATO
Compósito Cimentício Projetado (ECC) é um tipo de compósitos cimentícios reforçados com fibras de alto desempenho melhorados com bom comportamento de tração, compressão e flexão. O ECC é conhecido por seu comportamento de endurecimento de tensão sob tensão e tem sido cada vez mais aplicado na prática de engenharia. O processo de adicionar duas ou mais fibras em uma mistura é conhecido como hibridização. Os drives de compósitos híbridos se beneficiam de cada uma das fibras individuais adicionadas e exibem maior capacidade de resistência e deformação em comparação com os compostos de fibra monofibra. As principais aplicações da CEC são um reforço estrutural na construção e também a hibridização de fibras orgânicas são válidas apenas para condições subaquáticas e fornecerão testes adicionais relativos à capacidade de combustão ou inflamabilidade. Este trabalho apresenta os resultados obtidos a partir de três misturas de ECC (PVA, PP, STEEL) e quatro Compósitos Cimentícios Híbridos de Engenharia (HECC) com diferentes combinações de fração volumétrica com PVA, PP, STEEL. Os estudos experimentais foram realizados para investigar os comportamentos mecânicos de CEC e HECC. Os resultados indicam que este processo de hibridação tem um desempenho notável na resistência à compressão, resistência à tração direta e resistência à flexão.
\end{abstract}

Palavras-chave: Compósito Cimentício Projetado, Resistência à Compressão, Força Flexural, Resistência à Tração Direta, Compósitos com Materiais Queimados Orgânicos 
Concrete is brittle in nature [1]. The application of load in normal concrete structures, creates a number of macroscopically visible cracks when the stress reaches the tensile strength of concrete. These stress failures are due to seismic loads, vertical loads and accidental loads. Due to distress cracks, water and other chemical agents penetrate into the concrete and leads to the corrosion of steel reinforcements.

To reduce the width of the crack, a high performance fiber-reinforced cementitious composites known as Engineered Cementitious Composites (ECC) [2] have been developed and are used in tension zone to minimise the crack width, which has an ultimate strength higher than their first cracking strength with the formation of multiple cracks during inelastic deformation [3].

ECC is a type of improved high-performance fiber reinforced cementitious composite (HPFRCC) [4,5]. The ECC and fiber reinforced concrete have similar materials, which includes sand, cement, water, fiber, and some chemical additives. However, to maintain the unique properties of ECC, coarse aggregate is not included [6,7,8]. Though the fiber reinforced concrete has reasonable strain capability, ECC exhibits more tensile strain value ranging from $3 \%$ to $7 \%$ with the same fiber volume fraction of typically around $2 \%$ or less.

In general, it also exhibits strain capacities 500-600 times higher than normal concrete [9, 10, 11]. The exhibition of tensile strain in ECC depends on the micro mechanical design [12]. The mixing procedure for ECC is similar to the normal conventional concrete. The main aim of ECC is to improve ductility and toughness [13]. ECC is economical by a reduction in the usage of fiber and notable for strength andductility characteristics. The ECC is commonly used in structures that have a high energy absorption capacity.

In order to increase the corrosive resistance nature of structures, ECC is used as a shielding layer. Other targets of ECC include expansion joints in highway pavements [14], interior beam-column connection [15], rigid framed railway bridges [16], RC slabs [17] and expansion joints in bridge decks [18].

The process of adding more than one fiber in a mix is known as hybridization. The hybridization effect of two or more fibers on the cementitious materials reinforcement was investigated recently [3]. The hybrid composite drives benefits from each of the individual fibers and exhibited improved ultimate strength and strain capacity compared to the mono-fiber composites [19, 20, 21, 22, 23].ECC is a high-performance cementitious composite with excellent ductility behavior [24] and it has an average fiber content with short random PVA fiber. The tensile strength, flexural strength and relative toughness of mono-fiber based composite are lesser when compared to hybrid ECC [25]. In order to further enhance the structural performance of ECC in structural applications, development of a hybrid engineered cementitious composite has been made which enhanced the tensile strength, flexural strength and relative toughness [26]. The number of existing structures undergo cracking in tension zone due to stress failures for which an attempt can also be made to repair the cracks in tension zone by using proper ECC composition which will increase the life span of structures. PVA and polypropylene (PP) have better performance in strain hardening, ductility with least amount of load under tension and thus, it is categorized under low modulus fiber [27]. The high modulus fibers such as glass, steel and carbon fibers exhibit high tensile strength, toughness and in build brittle nature which does not allow for strain hardening and ductility [28, 29, 30, 31].

For this study, seven mix combinations including these three mixes like Polyvinyl Alcohol fiber of volume fraction $2 \%$, polypropylene fiber of volume fraction $2 \%$ and steel fiber of volume fraction $2 \%$ have been used. These three mixes are mono ECC mixes. Another four mixes like polyvinyl alcohol fiber of volume fraction $1 \%$ is hybridized with polypropylene fiber of volume fraction $1 \%$ and polyvinyl alcohol fiber of volume fraction $1 \%$ is hybridized with steel fiber of volume fraction $1 \%$ and polyvinyl alcohol fiber of volume fraction $1.35 \%$ is hybridized with polypropylene fiber of volume fraction $0.65 \%$ and polyvinyl alcohol fiber of volume fraction $1.35 \%$ is hybridized with steel fiber of volume fraction $0.65 \%$ has been used. These four mixes are used to develop a new HECC. ECC with $2 \%$ volume fraction of PVA fiber is kept as reference mix.

\section{MATERIALS AND METHODS}

\subsection{Materials}

For this study, the Class F fly ash and ordinary Portland Cement (OPC) of 53 grade are used as shown in Table 1. 
Table 1: Chemical composition of cement and fly ash (\% of ingredients)

\begin{tabular}{c|c|c|c|c|c|c|c}
\hline & $\mathrm{CaO}(\%)$ & $\mathrm{SiO}_{2}(\%)$ & $\mathrm{Al}_{2} \mathrm{O}_{3}(\%)$ & $\mathrm{Fe}_{2} \mathbf{O}_{3}(\%)$ & $\mathbf{M g O}(\%)$ & $\mathbf{S O}_{3}(\%)$ & $\begin{array}{c}\text { Alkalines } \\
(\%)\end{array}$ \\
\hline Cement & 63.71 & 22.3 & 4.51 & 3.39 & 1.77 & 2.59 & 1.73 \\
\hline Fly Ash & 1 & 60.21 & 26.08 & 4.80 & 2.25 & 3.25 & 1.41 \\
\hline
\end{tabular}

For this study, the composite materials used are polyvinyl alcohol fiber (PVA), polypropylene fiber (PP) and steel fiber. The length, Diameter, Mechanical Properties of the fiber, are as shown in Table 2.
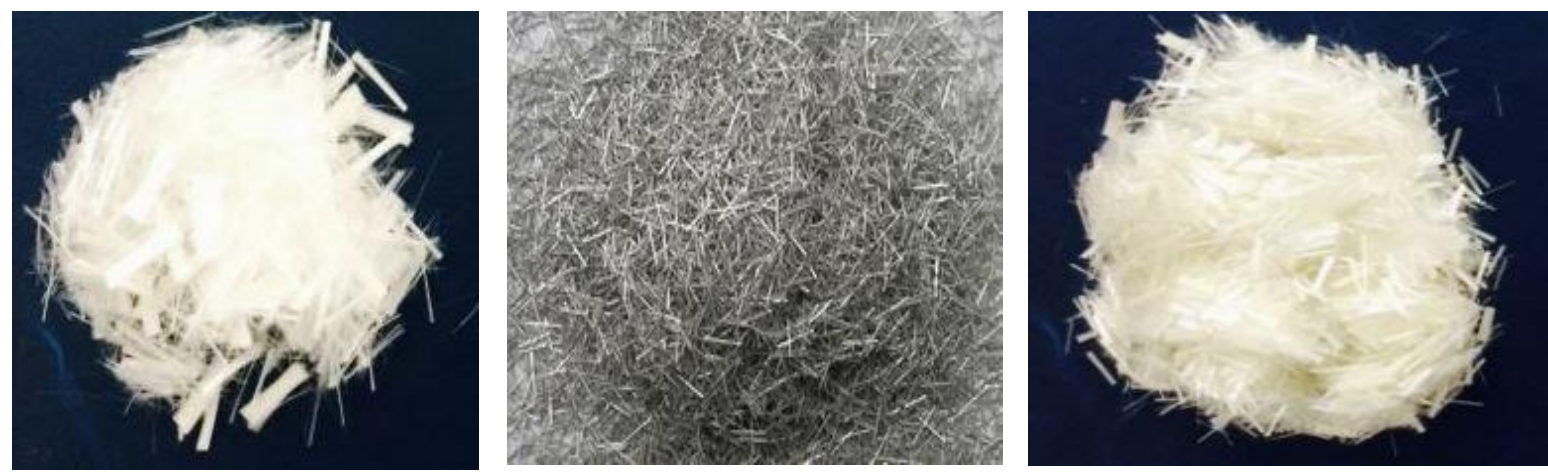

Figure 1: Three types of fibers used for this study

Table 2: Physical and mechanical properties of different fibers

\begin{tabular}{c|c|c|c|c|c|c|c}
\hline Fibre & Diameter & Length & I/d ratio & Density & $\begin{array}{c}\text { Nominal } \\
\text { tensile } \\
\text { strength } \\
{[\mathrm{MPa}]}\end{array}$ & $\begin{array}{c}\text { Elongation } \\
\text { at break [\%] }\end{array}$ & $\begin{array}{c}\text { Young's modu- } \\
\text { lus } \\
{[\mathbf{M P a}]}\end{array}$ \\
\hline PVA & 39 & 12 & 308 & 1.3 & 1600 & 6 & 42.5 \\
\hline PP & 37 & 10 & 270 & 0.91 & 400 & 23 & 2.5 \\
\hline Steel & 300 & 12 & 40 & 7.9 & 2000 & 4.5 & 175 \\
\hline
\end{tabular}

\section{Polyvinyl Alcohol (PVA) Fiber}

PVA Fiber

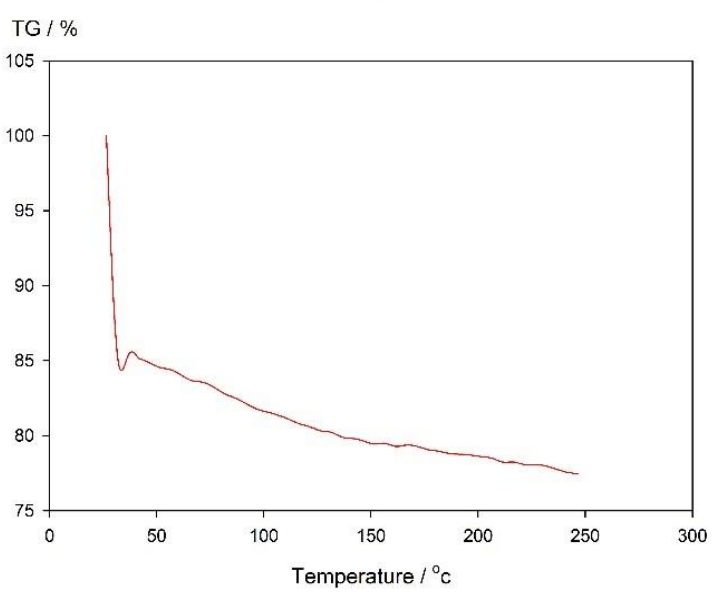

Steel Fiber

\section{Polypropylene (PP) Fiber}

PP Fiber

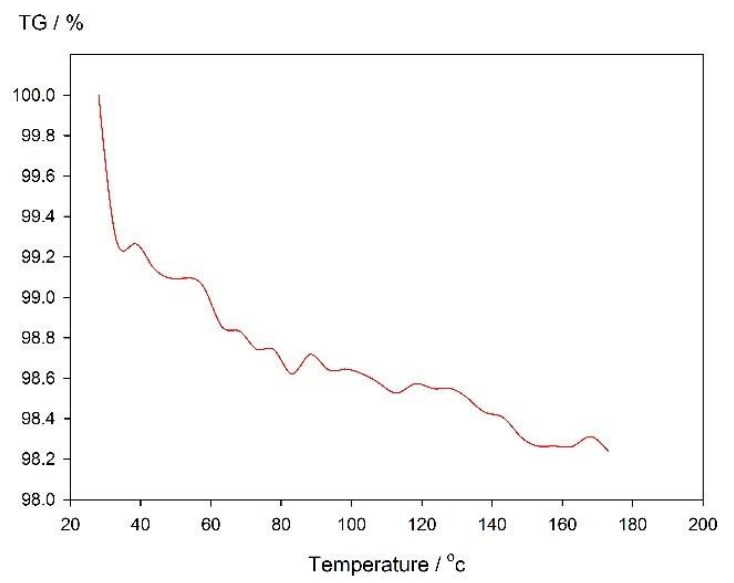

Figure 2: Thermogravimetric Analysis of PVA and PP fiber 
In this study, new fiber hybridization in ECC has been developed. The mix proportions of ECC mixes are as shown in Table 3. To maintain desired consistent fresh ECC characteristics, the conplast SP430 has been used as a high range water reducing agent in the mix. Figure 1. shows the fibers used in this study and Figure 2. shows the thermogravimetric analysis of PVA and PP fiber, from the results it has been observed that the melting point of PVA and PP fiber is found to be $250.3{ }^{\circ} \mathrm{C}$ and $176.1{ }^{\circ} \mathrm{C}$ respectively.

In ECC mix, the reference ECC 1 mix with PVA fiber of volume fraction $2.0 \%$ is added and reference ECC 2 mix with PP fiber of volume fraction $2.0 \%$ is added and another reference ECC 3 mix with steel fiber of volume fraction $2 \%$ is added. To improve the strain hardening capacity, HECC 1 mix with PVA fiber and PP fiber of volume fraction $1.35 \%$ and $0.65 \%$ respectively is added and in HECC 2 mix, PVA fiber and steel fiber of volume fraction $1.35 \%$ and $0.65 \%$ is added respectively and in HECC 3 mix, PVA fiber and PP fiber of volume fraction $1 \%$ and $1 \%$ respectively is added and in HECC 4 mix, PVA fiber and steel fiber of volume fraction $1 \%$ and $1 \%$ is added respectively.

\subsection{Specimen Preparation}

To prepare the specimen, Cement, sand and fly ash have been mixed and then water is added to the mix and mixed for another 5 minutes [22]. Later fibers are mixed with cement paste slowly and mixed until fibers are mixed evenly. To minimize the effect of thixotropy, the mixing time of the concrete mix is extended (not more than 15 minutes). Increase in duration of fiber reinforced mix reduces the balling effects [32, 33]. Now the prepared concrete mix is placed in the moulds and has not been vibrated as the mix is highly workable. Specimens are kept at room temperature for 24 hours. Later the specimens are demoulded and then cured in water for 28 days. After 28 days, all the tests have been performed on the respective specimens. Table. 4 shows the specimen details used for this investigation.

Table 3: Mix proportion of ECC

\begin{tabular}{|c|c|c|c|c|c|c|c|c|}
\hline \multirow{2}{*}{ Mix ID } & \multirow[t]{2}{*}{ Cement } & \multirow[t]{2}{*}{ Fly ash } & \multirow[t]{2}{*}{ Sand } & \multirow{2}{*}{$\begin{array}{c}\text { Water/Binder } \\
\text { ratio }\end{array}$} & \multirow{2}{*}{$\begin{array}{c}\begin{array}{c}\text { Super Plasti- } \\
\text { cizer }\end{array} \\
{[\%]}\end{array}$} & \multicolumn{3}{|c|}{ Fiber (\%) } \\
\hline & & & & & & PVA & PP & Steel \\
\hline ECC 1 & 1 & 0.43 & 0.71 & 0.35 & 1 & 2 & -- & -- \\
\hline ECC 2 & 1 & 0.43 & 0.71 & 0.35 & 1 & -- & 2 & -- \\
\hline ECC 3 & 1 & 0.43 & 0.71 & 0.35 & 1 & -- & -- & 2 \\
\hline HECC 1 & 1 & 0.43 & 0.71 & 0.35 & 1 & 1.35 & 0.65 & -- \\
\hline HECC 2 & 1 & 0.43 & 0.71 & 0.35 & 1 & 1.35 & -- & 0.65 \\
\hline HECC 3 & 1 & 0.43 & 0.71 & 0.35 & 1 & 1 & 1 & -- \\
\hline HECC 4 & 1 & 0.43 & 0.71 & 0.35 & 1 & 1 & -- & 1 \\
\hline
\end{tabular}

Table. 4: Specimen details

\begin{tabular}{c|c|c|c|c}
\hline Test type & $\begin{array}{c}\text { Specimen dimensi- } \\
\text { on }(\mathbf{m m})\end{array}$ & Tested after curing & $\begin{array}{c}\text { Total specimen } \\
\text { cast }\end{array}$ & Test Standards \\
\hline $\begin{array}{c}\text { Compression strength } \\
\text { test }\end{array}$ & $70.7 \times 70.7 \times 70.7$ & $3,7,14$ and 28 days & 84 & IS 4031-Part 6 \\
\hline Elastic modulus & $\begin{array}{c}100 \mathrm{~mm} \text { diameter } \mathrm{x} \\
200 \mathrm{~mm} \text { length }\end{array}$ & $3,7,14$ and 28 days & 84 & ASTM C39 \\
\hline Flexural strength & $25 \times 60 \times 350$ & 28 days & 21 & ASTM C 1609 \\
\hline Tensile strength & $30 \times 30 \times 330$ & 28 days & 21 & ASTM D3039 \\
\hline
\end{tabular}




\subsection{Test Methods}

\subsubsection{Uniaxial Compression and Elastic Modulus}

To find the compressive strength of ECC, the concrete cube of size $70.7 \times 70.7 \times 70.7 \mathrm{~mm}$ has been tested at 3,7,14 and 28 days as per code IS 4031-Part 6 [34]. The cube specimen is placed in the testing machine and the load is applied axially until it collapses. The maximum load at which the cube specimen breaks is the compressive load. The same procedure has been followed for the specimens of size $200 \mathrm{~mm}$ length and $100 \mathrm{~mm}$ diameter to find the elastic modulus of ECC mixes as per ASTM C39 [35]. Figure 3. shows the cube under compression load.

Figure 3: Uniaxial compression test

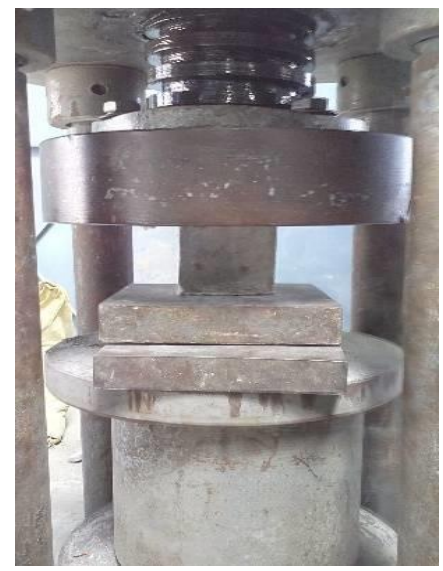

\subsubsection{Direct tensile}

To determine the direct tensile strength of ECC (Figure 4), the dog bone specimen of size $350 \times 30 \times 30 \mathrm{~mm}$ with $60 \mathrm{~mm}$ gauge length is used after 7,14 and 28 days curing. The Specimen of gauge length $80 \mathrm{~mm}$ and cross section of $30 \mathrm{~mm}$ thick and $30 \mathrm{~mm}$ width is used to find tensile strength of ECC as per ASTM D3039 [36]. Figure 4. shows the direct tensile test setup.

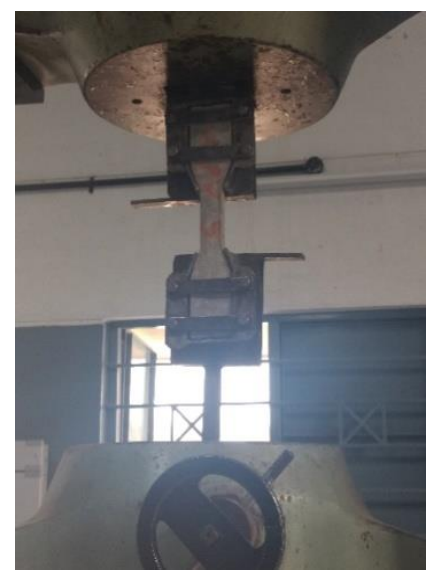

Figure 4: Dog bone specimen under direct tensile load.

\subsubsection{Flexural strength}

The three point load test on prism specimen of size $25 \times 60 \times 350 \mathrm{~mm}$ is used to find out the flexural performance of ECC prism specimens. Zwick/Roell Z100 universal testing machine of capacity $100 \mathrm{kN}$ is used for the flexural test as per ASTM C 1609 [37]. The prism specimen is placed on two parallel supporting pins and the loading force was applied in the middle by means of deflection control machine. The deflection is measured using optical video sensor. 


\section{RESULTS}

\subsection{Compressive Strength}

To derive the compressive strength of the ECC mixes for 3, 7, 21 and 28 days of curing, seven different mixes are tested and average values from three specimens whave been taken. After 28 days curing, the compressive strength for mixes ECC 1, ECC 2, ECC 3, HECC 1, HECC 2, HECC 3, HECC 4 were $51 \mathrm{MPa}, 47.8 \mathrm{MPa}$, 54.1 MPa, 48 MPa, 51.8 MPa, 50.85 MPa and 52.1 MPa respectively. From the results, it can be noted that there is a prominent achievement in strength due to the presence of steel and combination of PVA and steel fibers. The compressive strength after 3 days curing for mixes ECC 1, ECC 2, ECC 3, HECC 1, HECC 2, HECC 3, HECC 4 were 9.4 MPa, 9.1 MPa, 10.51 MPa, 9.1 MPa, 9.74 MPa, 9.45 MPa and 9.86 $\mathrm{MPa}$ respectively. The compressive strength for mixes ECC 1, ECC 2, ECC 3, HECC 1, HECC 2, HECC 3, HECC 4 after 7 days curing are 28.8 MPa, 27.7 MPa, 31 MPa, 27.9 MPa, 30.3 MPa, 28.1 $\mathrm{MPa}$ and 30.3 $\mathrm{MPa}$ respectively. The compressive strength for mixes ECC 1, ECC 2, ECC 3, HECC 1, HECC 2, HECC 3, HECC 4 were 38.2 MPa, 37.5 MPa, 48.5 MPa, 45.8 MPa, 46.8 MPa, 46.9 MPa and 47.6 MPa respectively after 14 days curing. The typical failure pattern of ECC cubes under uniaxial compression test is as shown in Figure 5.

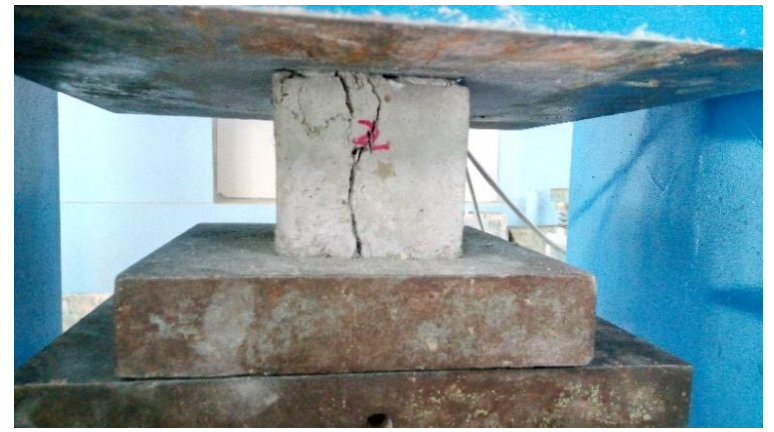

Figure 5: Failure pattern of ECC specimen

Three specimens per mix are tested to find the compressive strength of mixes ECC 1, ECC 2, ECC 3, HECC 1, HECC 2, HECC 3, HECC 4 at the age of 3,7,14 and 28 Days and the changing of average compressive strength of the seven ECC mixes with time is shown in Figure 6.

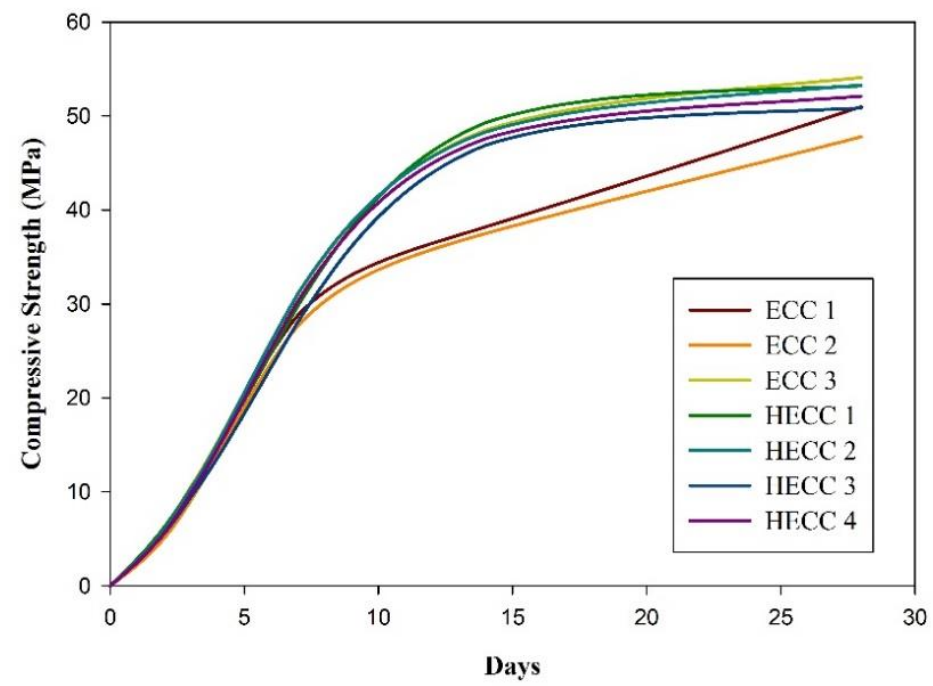

Figure 6: Compressive Strength of 7 mix

It can be seen that there is a considerable difference in mix ECC 1, ECC 2 between other mixes and no significant difference between the compressive strengths for ECC 3, HECC 1, HECC 2, HECC 3, HECC 4 mixes. For ECC 1, ECC 2, HECC 3 mix, the strength of the material at the age of 3days is around $21 \%$ of that at the age of 28 days while for ECC 3, HECC 1, HECC 2, HECC 7 it is $27 \%$ of that at the age of 28 days. 
The maximum value of compressive strength for the ECC mixes at the age of 28 days is around $54 \mathrm{MPa}$, which is higher than that of the normal conventional concrete with the same water-cement ratio, while the Young's modulus for the ECCs is slightly lower than that of conventional concrete with the same compressive strength. This might be due to the lack of coarse aggregates in the ECC matrix.The compressive stressstrain relationship obtained from the compressive test for the seven ECC mixes tested at the age of 28 days is shown in Figure 7. The specimens are tested until the specimen fails. It can be seen that the average compressive strength of ECC 3, HECC 1, HECC 2, HECC 4 are higher than that of ECC 1, ECC 2, HECC 3 . After 28 days curing, the compressive strength of ECC mix should be around 20-95 MPa as per there commendation of Victor Li [38] and moreover the compressive strength of all ECC mixes are within the range. However, ECC specimens shows high ductile nature and significantly spalling does not occur in the specimens due to the bridging of fibers within the specimen [11].

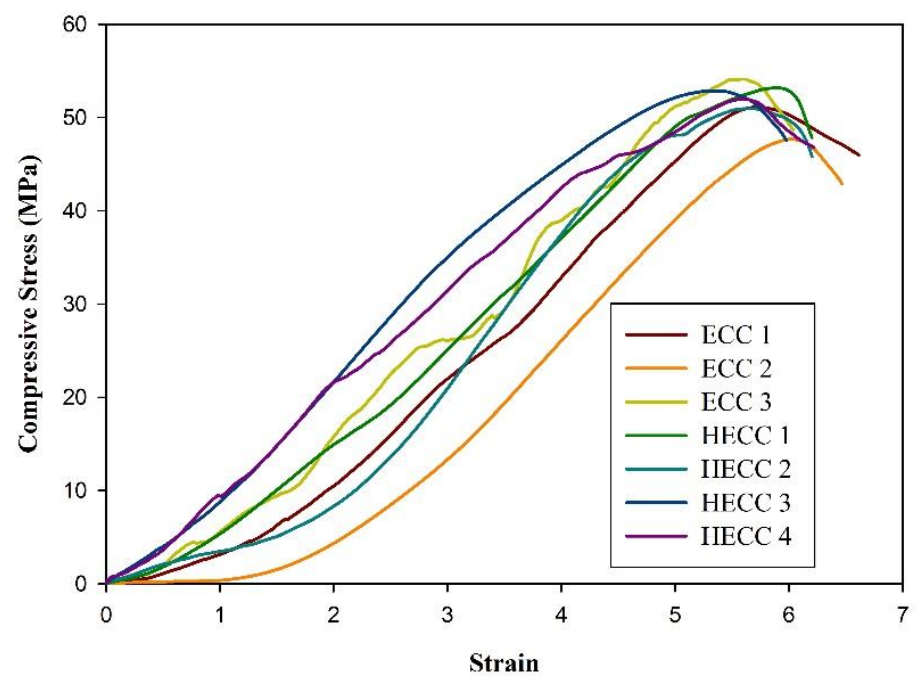

Figure 7: Compressive Stress-Strain Curve.

\subsection{Direct Tensile Strength}

Nowadays, ECC is being used in structural components because of its tensile strain hardening, crack mitigation, modulus rupture nature. After 28 days of curing, the tensile strength of ECC for mixes ECC 1, ECC 2, ECC 3, HECC 1, HECC 2, HECC 3, HECC 4 were 5.53 MPa, 4.55 MPa, 7.24 MPa, 4.94 MPa, $\quad 6.3 \mathrm{MPa}, 5.09$ $\mathrm{MPa}$ and $6.39 \mathrm{MPa}$ respectively. The tensile strength of ECC for mixes ECC 1, ECC 2, ECC 3, HECC 1, HECC 2, HECC 3, HECC 4 after 14 days curing are 2.92 MPa, 2.29 MPa, 4.19 MPa, 2.66 MPa, 3.79 MPa, 2.73 $\mathrm{MPa}$ and $3.84 \mathrm{MPa}$ respectively. The tensile strength of ECC after 7 days of curing for mixes ECC 1, ECC 2, ECC 3, HECC 1, HECC 2, HECC 3, HECC 4 are 1.38 MPa, 1.23 MPa, 2.09 MPa, 1.79 MPa, $1.84 \mathrm{MPa}$,

1.85 $\mathrm{MPa}$ and 1.91 $\mathrm{MPa}$ respectively. The tensile strength of ECC is neglected as it is very small for 3 days curing. After 28 days curing, the ultimate tensile strength of ECC mix should be around 4-12 MPa as per the recommendation of Victor $\mathrm{Li}$ [11] and in addition to that the direct tensile strength of all ECC mixes are within the range. The failure pattern of ECC is shown as in Figure 8. 


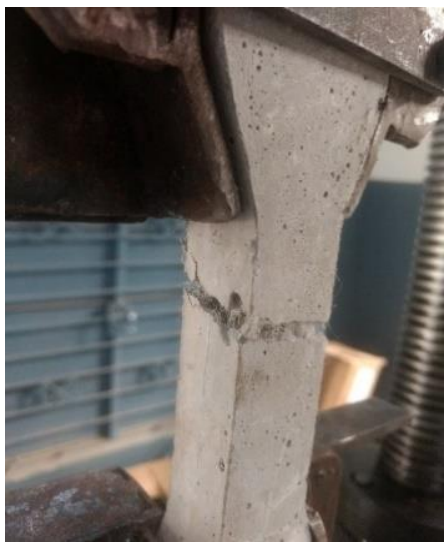

Figure 8: Failure pattern of ECC.

\subsection{Flexural Strength}

The flexural performance of ECC imitates the ductile behavior of the mix [27]. After 28 days curing, the flexural strength for mixes ECC 1, ECC 2, ECC 3, HECC 1, HECC 2, HECC 3, HECC 4 are 22.6 MPa, 18.40 $\mathrm{MPa}, 23.98 \mathrm{MPa}, 21.95 \mathrm{MPa}, 21.88 \mathrm{MPa}, 21.03 \mathrm{MPa}$ and $24.32 \mathrm{MPa}$ respectively. The flexural strength after 14 days curing for mixes ECC 1, ECC 2, ECC 3, HECC 1, HECC 2, HECC 3, HECC 4 are $19.21 \mathrm{MPa}, 14.77$ $\mathrm{MPa}, 21.33 \mathrm{MPa}, 18.75 \mathrm{MPa}, 20.45 \mathrm{MPa}$ and 20.79 MPa respectively. The flexural strength for mixes ECC 1, ECC 2, ECC 3, HECC 1, HECC 2, HECC 3, HECC 4 after 7 days curing are $6.33 \mathrm{MPa}, 5.30 \mathrm{MPa}, 6.86 \mathrm{MPa}$, 6.21 MPa, 6.65 MPa, 6.11 MPa and 6.79 MPa respectively. The failure pattern of ECC is shown as in Figure 9.

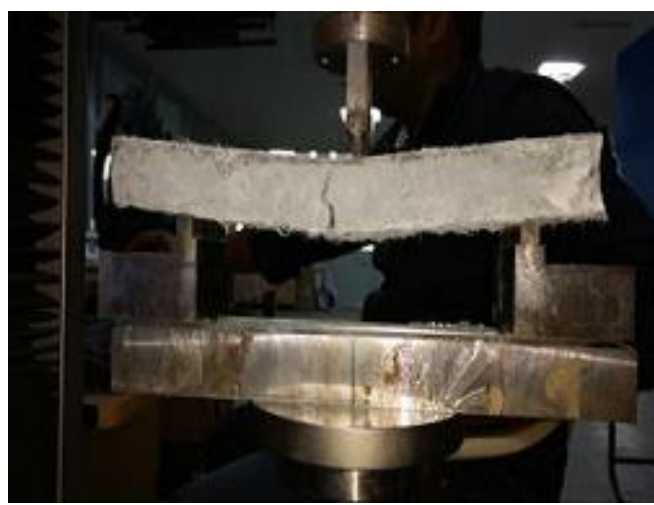

Figure 9: Failure pattern of ECC

The flexural stress-strain relationship at the mid-span of the beams obtained from the bending test for all seven mix beams is shown as in Figure 10. The specimens have been tested upto failure. The corresponding average ultimate strain for ECC 1, ECC 2, ECC 3, HECC 1, HECC 2, HECC 3, HECC 4 were 0.18, 0.28, 0.17, $0.13,0.16,0.15$ and 0.2 respectively. The average flexural strength of the ECC 3 and HECC 2 is greater than that of all other mixes, and the largest value $(23.98 \mathrm{MPa})$ of the flexural strength obtained from the testing of one of the mixes is $25 \%$ greater than the least one $(18.40 \mathrm{MPa})$ obtained from the testing of one of the all mixes. The relationship between the flexural stress and the mid-point deflection of the all seven mixes shows that the ECC3 mix can sustain greater load than all other mixes. Moreover, after reaching the flexural strength the deflection of the ECC 1, ECC 2, HECC 1, HECC 3 mixes increases faster than that of the remaining mixes. After 28 days curing, the flexural strength of ECC mix should be around 10-30 MPa as per the recommendation of Victor Li [11] and the flexural strength of all ECC mixes are within the range. Being ductile in nature the formation of multiple cracks in the prism are found to increase the performance of the ECC [39]. 
Fracture energy of the prism is calculated as the area enclosed by the stress-strain curve to the point with the maximum flexural strength, and thus, the fracture energy of the mix HECC 4 is greater than all other mixes.

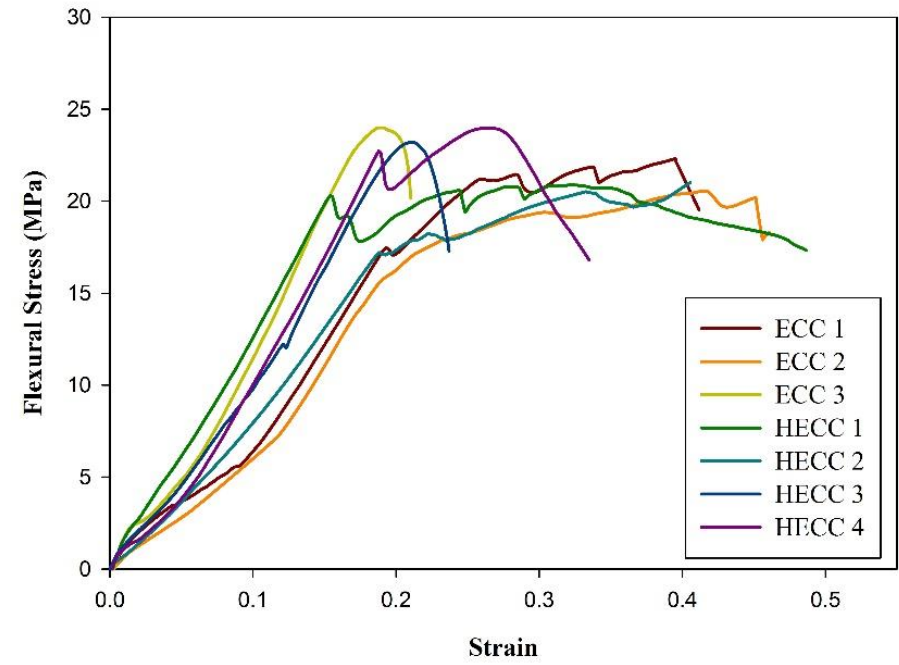

Figure 10: Flexural Stress-Strain Curve

\subsection{Elastic Modulus Strength}

After 28 days curing, the youngs modulus for mixes ECC 1, ECC 2, ECC 3, HECC 1, HECC 2, HECC 3, HECC 4 are 23.8 GPa, 22.1 GPa, 26.1 GPa, 24.3 GPa, 24.3 GPa, 24.5 GPa and 25.1 GPa respectively. The Young's modulus after 14 days curing for mixes ECC 1, ECC 2, ECC 3, HECC 1, HECC 2, HECC 3, HECC 4 are $20.7 \mathrm{GPa}, 20.8 \mathrm{GPa}, 22.9 \mathrm{GPa}, 20.6 \mathrm{GPa}, 19.9 \mathrm{GPa}, 20.89 \mathrm{GPa}$ and $21.6 \mathrm{GPa}$ respectively. The Young's modulus for mixes ECC 1, ECC 2, ECC 3, HECC 1, HECC 2 after 7 days curing are $17.9 \mathrm{GPa}, \quad 18.1 \mathrm{GPa}$, 19.7 GPa, 16.78 GPa, 17.9 GPa, 17.9 GPa and 18.3 GPa respectively. The Young's modulus for mixes ECC 1, ECC 2, ECC 3, HECC 1, HECC 2, HECC 3, HECC 4 are 9.2 GPa, 9.1 GPa, 10.24 GPa, $10.34 \mathrm{GPa}, 9.75$ $\mathrm{GPa}, 10.1 \mathrm{GPa}$ and $9.8 \mathrm{GPa}$ respectively after 3 days curing.

The Young's modulus of the seven mixes is tested at the age of 3, 7, 14, and 28 days and the average results from the specimens tested are shown in Figure 11. After 28 days of curing, young's modulus of ECC mix should be around 18-34 GPa as per the recommendation of Victor Li [11] and the young's modulus of all ECC mixes are found to be within the range. It can be seen that the Young's modulus for ECC 1, ECC 2 mixes are similar and other mixes are similar at the age of 14 and 28 days. However, the values of all mixes are similar for 3 days.

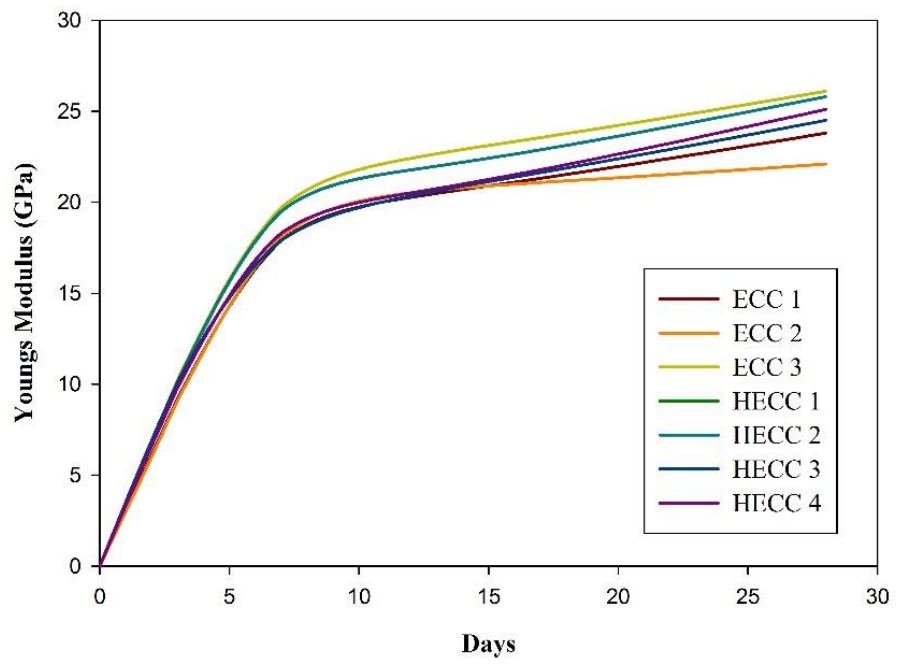

Figure 11: Young's Modulus of ECC mixes 


\section{CONCLUSIONS}

According to the results obtained from the present study, the following conclusions can be drawn,

The compressive strength of ECC 3 mix is maximum which increases by $5.89 \%$ than the conventional reference mix ECC 1 whereas in hybridized mixes HECC 3 is maximum which increases by $2.13 \%$ than the conventional reference mix ECC 1.

From the compressive stress-strain curve, it is noted that load carrying capacity of all the mixes are identical except ECC 2.

The tensile strength of ECC 3 mix is maximum which increases by $26.78 \%$ than the reference mix ECC 1 whereas in hybridized mixes HECC 3 is maximum which increases by $14.43 \%$ than the conventional reference mix ECC 1.

The flexural strength of ECC 3 mix is maximum which increases by $5.92 \%$ than the conventional reference mix ECC 1 whereas in hybridized mixes HECC 3 is maximum which increases by $7.33 \%$ than the conventional reference mix ECC 1.

From the flexural stress-strain curve, it is found that the increase in the flexural strain due to presence of low modulus fiber in the HECC mix. Except ECC 3 and HECC 4 all other mixes have excellent strain hardening.

The young's modulus of ECC 3 mix is maximum which increases by $8.8 \%$ than the conventional reference mix ECC 1 whereas in hybridized mixes HECC 3 is maximum which increases by $5.31 \%$ than the conventional reference mix ECC 1 .

The compressive, young's modulus and tensile strength increases with the addition of steel fibers whereas the flexural strength increase with the addition of both PVA and steel fibers.

The compressive, young's modulus, flexural and tensile strength are low for both PP fiber mixes and hybridization of PP fiber with steel fiber.

From the mechanical properties it is noted that PVA fiber hybridization has more strength parameters when compared with PP fiber hybridization. However, the strain hardening of ECC mixes increases with increase in presence of PP and PVA fibers.

\section{ACKNOWLEDGMENTS}

The PVA fibers used in this research work has been funded by Kuraray private limited, India. Compressive strength and Flexural Strength test is conducted at PSGTECHS COE INDUTECH (Promoted by Ministry of Textiles - Government of INDIA), Department of Textile Technology/Automobile Engineering- PSG College of Technology, Coimbatore.

\section{BIBLIOGRAPHY}

[1] KOTSOVOS M., "Concrete. A brittle fracturing material”, Matériaux et Construction, v.17, n. 2, pp.107, 1984.

[2] LI V.C., "On engineered cementitious composites (ECC)”, Journal of advanced concrete technology, v.1, n. 3, pp.215-230, 2003.

[3] LI, V.C., “Advances in ECC research”, ACI Special Publications, v.206, n. 373-400, 2002.

[4] KRISHNARAJA, A.R., "Mechanical Properties of Engineered Cementitious Composites", International Journal of ChemTech Research, v.10, n. 8, pp.341-347, 2017.

[5] KRISHNARAJA, A.R., KANDASAMY, S. "Flexural Performance of Engineered Cementitious Compositelayered Reinforced Concrete Beams", Archives of Civil Engineering , 2017.

[6] KIM, J.-K., KIM, J.-S., HA, G.J., et al., "Tensile and fiber dispersion performance of ECC (engineered cementitious composites) produced with ground granulated blast furnace slag", Cement and Concrete Research, v.37, n. 7, pp.1096-1105, 2007.

[7] YANG, E.-H., YANG, Y., LI, V.C. "Use of high volumes of fly ash to improve ECC mechanical properties and material greenness", ACI materials journal, v.104, n. 6, pp.620-628, 2007.

[8] GARCEZ E.O., Investigação do comportamento de Engineered Cementitious Composites reforçados com fibras de polipropileno como material para recapeamento de pavimentos, Tese de D.Sc., UFRGS, Rio 
Grande do Sul, Brasil, 2009.

[9] SILVA, E., COELHO. J., BORDADO, J., "Strength improvement of mortar composites reinforced with newly hybrid-blended fibres: Influence of fibres geometry and morphology", Construction and Building Materials, v. 40, n. 473-480, 2013.

[10] AHMED, S., MAALEJ, M., "Tensile strain hardening behaviour of hybrid steel-polyethylene fibre reinforced cementitious composites”, Construction and Building Materials, v.23, n. 1, pp.96-106, 2009.

[11] LI, V.C., Engineered Cementitious Composites (ECC) Material, Structural, and Durability Performance, University of Michigan, 2008.

[12] KIM, Y.Y., KONG, H.-J., LI, V.C., "Design of engineered cementitious composite suitable for wetmixture shotcreting”, Materials Journal, v.100, n. 6, pp.511-518, 2003.

[13] QUDAH, S., M. MAALEJ, "Application of Engineered Cementitious Composites (ECC) in interior beam-column connections for enhanced seismic resistance", Engineering Structures, v.69, n. 235-245, 2014.

[14] QIAN, S., LI, V., ZHANG, H., et al., "Life cycle analysis of pavement overlays made with Engineered Cementitious Composites", Cement and Concrete Composites, v.35, n. 1, pp.78-88, 2013.

[15] ZHANG, R., MATSUMOTO, K., HIRATA, T., et al., "Application of PP-ECC in beam-column joint connections of rigid-framed railway bridges to reduce transverse reinforcements", Engineering Structures, v.86, n. 146-156, 2015.

[16] LEPECH, M.D., LI, V.C., “Application of ECC for bridge deck link slabs”, Materials and Structures, v.42, n. 9, pp.1185, 2009.

[17] AFEFY, H.M.E.-D., MAHMOUD, M.H. "Structural performance of RC slabs provided by pre-cast ECC strips in tension cover zone", Construction and Building Materials, v.65, n. 103-113, 2014

[18] KASAGANI H., RAO, C., The influence of hybrid glass fibres addition on stress-strain behaviour of concrete, Cement Wapno Beton, 2004.

[19] AHMED S.F.U., MIHASHI, H., "Strain hardening behavior of lightweight hybrid polyvinyl alcohol (PVA) fiber reinforced cement composites", Materials and structures, v.44, n. 6, pp.1179-1191, 2011.

[20] AHMED S.F., MAALEJ, M., PARAMASIVAM, P., “Analytical model for tensile strain hardening and multiple cracking behavior of hybrid fiber-engineered cementitious composites", Journal of materials in civil engineering, v.19, n. 7, pp.527-539, 2007.

[21] LAWLER, J.S., ZAMPINI, D., SHAH, S.P. "Microfiber and macrofiber hybrid fiber-reinforced concrete", Journal of Materials in Civil Engineering, v.17, n. 5, pp.595-604, 2005.

[22] KRISHNAMOORTHY, M., SIVARAJA, M., KRISHNARAJA, A.R. "Durability Studies on Polyethylene Terephthalate (PET) Fibre Reinforced Concrete", International Journal of Civil Engineering and Technology, v.8, n. 10, pp.634-640, 2017.

[23] CZOBOLY, O., LUBLÓY, E., HLAVIČKA, V., et al., "Fibers and fiber cocktails to improve fire resistance of concrete", Journal of Thermal Analysis and Calorimetry, v.128, n. 3, pp.1453-1461, 2017.

[24] PAKRAVAN, H.R., LATIFI, M., JAMSHIDI, M., "Ductility improvement of cementitious composites reinforced with polyvinyl alcohol-polypropylene hybrid fibers", Journal of Industrial Textiles, v.45, n. 5, pp.637-651, 2016.

[25] YAO, W., LI, J., WU, K., "Mechanical properties of hybrid fiber-reinforced concrete at low fiber volume fraction", Cement and concrete research, v.33, n. 1, pp.27-30, 2003.

[26] SAID, S.H., RAZAK, H.A., OTHMAN, I., "Flexural behavior of engineered cementitious composite (ECC) slabs with polyvinyl alcohol fibers", Construction and Building Materials, v.75, n. 176-188, 2015.

[27] LI, V.C., WANG, S., WU, C. “Tensile strain-hardening behavior of polyvinyl alcohol engineered cementitious composite (PVA-ECC)”, Materials Journal, v.98, n. 6, pp.483-492, 2001.

[28] BALAJI, S., THIRUGNANAM, G., "Behaviour of reinforced concrete beams with SIFCON at various locations in the beam”, KSCE Journal of Civil Engineering, v.22, n. 1, pp.161-166, 2018.

[29] BALAJI, S., THIRUGNANAM, G., "Flexural Strengthening of reinforced concrete beams using precast SIFCON laminates", Journal of structural Engineering, v.40, n. 262-267, 2013.

[30] VIGNESH, P., KRISHNARAJA, A., NANDHINI, N., "Study on mechanical properties of geo polymer concrete using m-sand and glass fibers", International Journal of Innovative Research in Science, Engineering and Technology, v.3, n. 2, pp.110-116, 2014. 
[31] SIVARAJA, M., KANDASAMY, S., "Characterization of concrete composites for energy absorption", Journal of Reinforced Plastics and Composites, v.27, n. 2, pp.135-144, 2008.

[32] BALÁZS, G.L., CZOBOLY, O., LUBLÓY, E., et al., "Observation of steel fibres in concrete with Computed Tomography”, Construction and Building Materials, v.140, n. 534-541, 2017.

[33] SIVARAJA, M., KANDASAMY, S., THIRUMURUGAN, A., "Mechanical strength of fibrous concrete with waste rural materials”, Journal of Scientific \& Industrial Research, v.69, 2010.

[34] STANDARD, I., IS 4031- Part 6: Methods of physical tests for hydraulic cement, Indian Standard, New Delhi,No., 1988.

[35] ASTM C., 39, Standard test method for compressive strength of cylindrical concrete specimens, ASTM International, 2001.

[36] STANDARD A., Standard test method for tensile properties of polymer matrix composite materials, ASTM D3039/D M, v.3039, n. 2008, 2008.

[37] ASTM C., 1609/C 1609M Standard Test Method for Flexural Performance of Fiber-Reinforced Concrete (Using Beam With Third-Point Loading), Replaces ASTM C, v.1018, n., 2009.

[38] PAKRAVAN, H.R., JAMSHIDI, M., LATIFI, M. "Study on fiber hybridization effect of engineered cementitious composites with low- and high-modulus polymeric fibers", Construction and Building Materials, v.112, n. 739-746, 2016.

[39] WANG, T., "Control of cracking in engineering structure: principle of "resist and release"'for alternative bay construction method cracking control of super long mass concrete", China Architecture \& Building Press, Beijing, 2007.

\section{ORCID}

Ammapalyam Ramasamy Krishnaraja

Subbaiyan Anandakumar

Murugesan Jegan

Krishnamoorthy Sampath Kumar

Thottipalayam Sakthivel Mukesh https://orcid.org/0000-0002-1521-1973

https://orcid.org/0000-0001-5270-0947

https://orcid.org/ 0000-0002-3725-9441

https://orcid.org/0000-0003-4063-8087

https://orcid.org/0000-0003-2991-1505 